\title{
Background and features of the WHO hand hygiene self-assessment framework
}

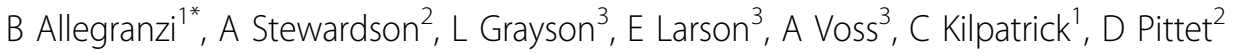 \\ From International Conference on Prevention \& Infection Control (ICPIC 2011) \\ Geneva, Switzerland. 29 June - 2 July 2011
}

\section{Introduction / objectives}

To develop a tool for self-assessment of $\mathrm{HH}$ resources, practice and promotion in healthcare facilities (HCF), based on the key components of the WHO Multimodal Hand Hygiene (HH) Improvement Strategy (MHHIS).

\section{Methods}

A task force (TF) of $\mathrm{HH}$ experts developed the tool and identified the following desired features: 1) to reflect the 5 components of the WHO MHHIS; 2) to include measurable indicators based on scientific evidence and expert consensus; 3 ) to be in the format of a userfriendly questionnaire; 4) to be associated with a score; $5)$ to be usable repetitively over time. Tool development steps were: 1 ) identification of indicators, score and format; 2) usability and reliability pilot testing; 3) review and finalization.

\section{Results}

The tool was named HH Self-Assessment Framework (HHSAF) and structured in 5 sections corresponding to the WHO MHHIS components (system change; training and education; evaluation and feedback; reminders in the workplace; institutional safety climate for $\mathrm{HH}$ ). 27 indicators were included and points assigned according to available evidence and importance attributed by experts. WHO implementation tools suited to the improvement of each indicator were referred to within the HHSAF. A score of maximum 100 points was established per each HHSAF section. According to the overall score, $4 \mathrm{HH}$ situation levels were identified: inadequate; basic; intermediate; advanced. Additional leadership criteria for $\mathrm{HH}$ reference centres were included. The draft was finalized according to results of usability and reliability tests.

${ }^{1}$ World Health Organization, Geneva, Switzerland

Full list of author information is available at the end of the article

\section{Conclusion}

Through a thorough development process, all desired features identified for an optimal $\mathrm{HH}$ self-assessment tool at HCF level were successfully fed into the HHSAF.

\section{Disclosure of interest}

None declared.

\section{Author details}

${ }^{1}$ World Health Organization, Geneva, Switzerland. ${ }^{2}$ University of Geneva Hospitals, Geneva, Switzerland. ${ }^{3}$ Hand Hygiene Task Force, World Health Organization, Geneva, Switzerland.

Published: 29 June 2011

doi:10.1186/1753-6561-5-S6-068

Cite this article as: Allegranzi et al:: Background and features of the WHO hand hygiene self-assessment framework. BMC Proceedings 20115 (Suppl 6):O68.

Submit your next manuscript to BioMed Central and take full advantage of:

- Convenient online submission

- Thorough peer review

- No space constraints or color figure charges

- Immediate publication on acceptance

- Inclusion in PubMed, CAS, Scopus and Google Scholar

- Research which is freely available for redistribution

\section{Ciomed Central}

(c) 2011 Allegranzi et al; licensee BioMed Central Ltd. This is an open access article distributed under the terms of the Creative Commons Attribution License (http://creativecommons.org/licenses/by/2.0), which permits unrestricted use, distribution, and reproduction in any medium, provided the original work is properly cited. 